\title{
PENDIDIKAN ETIKA ISLAM DALAM KELUARGA
}

\author{
Ahmad Arifai \\ Sekolah Tinggi Ilmu Tarbiyah Raudhatul Ulum Sakatiga \\ Email: ahmadarifai@stit-ru.ac.id
}

\begin{abstract}
Abstrak
Upaya mengembangkan "pendidikan" dalam rangka pembentukan kepribadian manusia yang utuh dan paripurna, merupakan salah satu dari sekian banyak kewajiban dalam syariat Islam. Pendidikan dalam ajaran Islam adalah kewajiban yang agung dan mulia, karena pada praktiknya pendidikan tidak hanyabernilai ibadah yang berisi ganjaran besar di sisi Allah SWT tetapi juga dapat mengangkat harkat dan martabat manusia menjadi orang yang berilmu dan berbudi pekerti luhur serta mampu membangun peradaban masyarakatnya. Untuk memelihara dan melestarikan misi kependidikan yang Islami itu, maka kegiatan pendidikan harus melaksanakan internalisasi nilai-nilai ke-Islaman yang berdimensi duniawi dan ukhrawi. Dasar pijakan yang dapat menentukan arah dan tujuan pendidikan yang berorientasi kepada dua dimensi tersebut, sebenarnya telah ditetapkan dalam Alquran dan As-Sunnah.
\end{abstract}

Kata Kunci: Pendidikan, Etika, Islam, Keluarga

\section{Pendahuluan}

Pada kehidupan manusia, seringkali kita dapati orang-orang yang tidak terlalu mengedepankan etika padahal tidak jarang orang-orang seperti itu adalah orangorang yang mempunyai pendidikan tinggi bahkan juga tidak jarang orang-orang yang mempunyai latar belakang pendidikkan yang agamis, dari keluarga yang taat dalam beragama, namun yang terjadi tidaklah sebagiamana yang diinginkan oleh agama. Pada hakikatnya tentu manusia itu sendiri mempunyai keinginan untuk menjadi orang yang baik-baik, ingin dihargai, dihormati, disegani, dan di tempatkan pada posisi yang tinggi, itulah sifat manusia pada umumnya yang sulit untuk dihilangkan.

Dalam dunia pendidikan misalnya belajar sekarang tidak lagi mengutamakan agama. Para pelajar lebih condong belajar pelajaran umum, sebab mempertimbangkan dunia, harta, nama dan jabatan. Banyak sudah mereka memilih tidak mempelajari agama, sebab ingin jadi ini dan itu, kalau belajar agama jadi apa dia kecuali akan sepi uang.

Namun manusia yang menyadari bahwa ia adalah seorang hamba yang mempunyai berbagai kekurangan ia akan tahu bagaimana semestinya bersikap dan bersifat. Sebelum melakukan suatu perbuatan, sebelum mengambil keputusan tentang sutau hal, maka terlebih dahulu dipertimbangkan: "apakah jika ku lakukan 


\section{Pendidikan Etika Islam dalam Keluarga}

\section{Ahmad Arifai}

perbuatan ini tidak menimbulkan kemurkaan Allah atas diriku, sehingga dikenakan hukuman masuk ke dalam lautan api yang menyala di akhirat kelak"? Atau, "apakah jika kulakukan perbutan ini tidak menjadi penghalang bagiku untuk mendapat villa yang indah dalam jannah akhirat?" (Hawi, 2008: 155).

Pembentukan etika yang baik pada diri seseorang tidak lepas dari peran para pendidik. Sebagai seorang pendidik yang bijak haruslah benar-benar mengenal dan memahami potensi dari peserta didik, sebagai ciptaan Allah yang sempurna, karena setiap anak memiliki potensi, keunikan dan kontribusi bagi dunia dan kehidupannya (Alpiyanto, 2012: 5)..

\section{Pembahasan}

a. Pengertian Etika

Di dalam Kamus Besar Bahasa IndonesiaEtika adalah ilmu yang berkenaan tentang yang baik dan yang buruk dan tentang hak dan kewajiban moral. Di dalam buku kompetensi Guru Pendidikan Agama Islam karangan Akmal Hawi etika berasal dari bahasa yunani "ethos" yang berarti watak kesusilaan atau adat. Identik dengan perkataan moral "Mos" yang dalam bentuk jamaknya "Mores" yang berarti juga adat atau cara hidup (Hawi, 2013: 49).

Dipandang dari segi ajaran yang mendasari etika Islam tergolong etika teologis. Menurut Hamzah Ya'qub pengertian etika teologis ialah yang menjadi ukuran baik dan buruknya perbuatan manusia, didasarkan atas ajaranTuhan. Segala perbuatan yang diperintahkan Tuhan itulah yang baik dan segala perbuatan yang dilarang oleh Tuhan itulah yang buruk (Hawi, 2013: 49).

Etika dari segi etimologi berasal dari bahasa yunani, ethos yang berarti watak kesusilaan atau adat. Dalam Encyclopedia Britanica, etika dinyatakan sebagai filsafat moral, yaitu studi yang sistematik mengenai sifat dasar dari konsep nilai baik, buruk, harus, benar, salah dan sebagianya.Adapun arti etika dari segi istilah telah dikemukakan para ahli dengan ungkapan yang berbeda-beda sesuai dengan sudut pandangnya.Berikut beberapa sudut pandang dari para ahli mengartikan etika:

Ahmad Amin, mengartikan etika adalah ilmu yang menjelaskan arti baik dan buruk, menerangkan apa yang seharusnya dilakukan oleh manusia, menyatakan tujuan yang harus dituju oleh manusia dalam perbuatan mereka dan menunjukkan jalan untuk melakukan apa yang seharusnya diperbuat (Putra, Wahyudin, 2005: 59).

Soegarda Poerbakawatja, mengartikan etika sebagai filsafat nilai, kesusilaantentang baik buruk, serta berusaha mempelajari nilai-nilai dan merupakan juga pengetahuan tentang nilai-nilai itu sendiri. Etika lebih bersifat teoritis filosofis sebagai acuan untuk mengkaji sistem nilai dan memandang perilaku secara universal (Aravik, 2018: 118). Berikutnya Austin Fogothey, sebagaimana dikutip Ahmad Charris Zubair mengatakan bahwa etika berhubungan dengan seluruh ilmu pengetahuan tentang manusia dan masyarakat sebagai antropologi, psikologi, sosiologi, ekonomi, ilmu politik, dan ilmu hukum. 
P-ISSN : 2541-3686

Frankena, sebagaimana juga dikutip Ahmad Charris Zubair mengatakan bahwa etika adalah sebagai cabang filsafat yaitu filsafat moral atau pemikiran filsafat tentang moralitas, problema moral, dan pertimbangan moral.

Dari beberapa defenisi etika tersebut, dapat segera diketahui bahwa etika berhubungan dengan empat hal sebagai berikut:

1. Dilihat dari segi obyek pembahasannya, etika berupaya membahas perbuatan yang dilakukan oleh manusia.

2. Dilihat dari segi sumbernya, etika bersumber dari akal fikiran atau filsafat. Sebagai hasil pemikiran, maka etika tidak bersifat mutlak, absolut, dan tidak pula univerasal, ia terbatas, dapat berubah, memiliki kekurangan, kelebihan dan sebagainya. Selain itu etika juga memanfaatkan berbagai ilmuyang membahas perilaku manusia seperti ilmu antropologi, psikologi, sosiologi, ilmu politik, ilmu ekonomi, dan sebagainya. Hal ini dimungkinkan karena berbagai ilmu yang disebutkan itu sama-sama memiliki obyek pembahasan yang sama dengan etika, yaitu perbuatan manusia.

3. Dilihat dari segi fungsinya, etika berfungsi sebagai penilai, penentu, dan penetap terhadap suatu perbuatan yang dilakukan oleh manusia, yaitu perbuatan tersebut akan dinilai baik, buruk, mulia, terhormat, hina, dan sebagainya. Dengan demikian etika lebih berperan sebagai konseptor terhadap sejumlah perilaku yang dilaksanakan oleh manusia. Peranan etika dalam hal ini tampak sebagai wasit atau hakim, dan bukan sebagai pemain. Ia merupakan konsep atau pemikiran mengenai nilai-nilai untuk digunakan dalam menentukan posisi atau status perbuatan yang dilakukan manusia. Etika lebih mengacu kepada pengkajian sistem nilai-nilai yang ada.

4. Dilihat dari segi sifatnya, etika bersifat relatif yakni dapat berubah-ubah sesuai dengan tuntutan zaman.

Pengertian etika lebih lanjut dikemukakan oleh Ki Hajar Dewantara. Menurutnya, etika adalah ilmu yang mempelajari soal kebaikan dan keburukan di dalam hidup manusia semuanya teristimewa yang mengenai gerak-gerik pikiran dan rasa yang dapat merupakan pertimbangan dan perasaan sampai mengenai tujuan yang dapat merupakan perbuatan (Putra, Wahyudin, 2005: 60).

\section{b. Peranan Keluarga dalam membentu Etika}

Keluaga adalah bentuk terkecil dari masyarakat. Dengan demikian cara suatu masyarkat tergambar pula dalam keluarga. Bentuk keluarga ada yang keluarga kecil, yang terdiri dari ayah, ibu, anak-anak dan ada juga keluarga luas (extended family) yang terdiri dari selain ayah, ibu, dan anak-anak.tetapi juga kakek, nenek, paman dan lain-lain. Kedudukan anggota keluarga berbeda-beda, demikian juga tanggung jawabnya. Di alam keluarga, ada aturan, norma yang tidak tertulis namun ditaati melalui pembinaan, contoh tauladan, pengalaman, kasih sayang, pujian, larangan dan hukuman (Departemen Agama, 1998: 5). 


\section{Pendidikan Etika Islam dalam Keluarga}

\section{Ahmad Arifai}

Hubungan sosial pertama bagi seoarng manusia begitu ia lahir kedunia adalah dengan kedua orang tuanya. Oleh karenanya setiap manusia wajib berbakti kepada kedua orang tuanya. Ini ditegaskan Allah dalam al-Qur'an surat an-Nisa' ayat 36

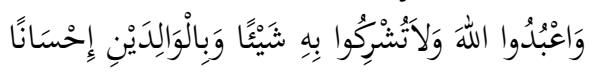

Artinya: Sembahlah Allah dan janganlah kamu mempersekutukan-Nya dengan sesuatupun.

Dan berbuat baiklah kepada kedua orang tua.

Berbakti kepada kedua orang tua itu merupakan suatu kewajiban, dalam hal ini Islam memberikan batasan-batasan tegas, bagaiman harus berbakti kepada kedua orang tua. Tetapi dilarang pula melebih-lebihkan kebaktian itu yang menjurus kepada penyembahan. Oleh karena itu Allah melarang mematuhi orang tua yang dapat menyebabkan musyrik kepada-Nya. Sebagaimana dimaksudkan dalam firman-Nya

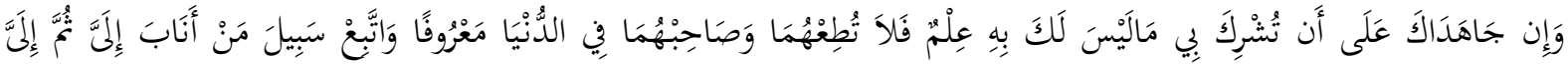

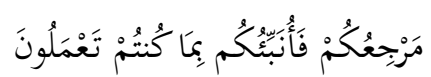

Artinya: Dan jika keduanya memaksakan untuk mempersekutukan dengan Aku sesuatu yang tidak ada pengetahuanmu tentang itu, maka janganlah kamu mengikuti keduanya dan pergaulilah keduanya di dunia dengan baik, dan ikutilah jalan orang yang kembali kepada-Ku, kemudian kepada-Kulah kembalimu, maka Ku beritakan kepadamu apa yang telah kamu kerjakan.

Tujuan pokok dari pendidikan Islam adalah pembentukan akhlak atau budi pekerti yaitu pendidikan yang sanggup melahirkan orang-orang yang bermoral, berjiwa bersih, berkemauan keras, tahu arti kewajiban, menghormati hak-hak asasi manusia, tahu membedakan yang benar dan yang salah, senantiasa mengingat Allah dalam setiap langkah dan perbuatan yang hendak dilakukannya.Sehingga akan terciptalah orang-orang yang mempunyai etika yang baik dalam keluarga maupun di masyarakat.

Dalam keluarga tentunya pendidikan ini ditugaskan kepada kedua orang tua. Mengingat orang tua adalah tumpuan harapan anak dalam kehidupannaya. Orang tua mempunyai andil besar dalam pertumbuhan dan perkembangan pribadi anak selanjutnya. Kemampuan, ketekunan, dan ketelatenan orang tua dalam membina pribadi anak-anak mereka dengan ajaran Islam, akan mewarnai pola tingkah laku yang ditunjukkan anak-anak itu dalam kehidupannya, masyarakat maupun dalam kehidupan berbangsa dan bernegara.

Anak-anak yang lahir dalam lingkungan agamis, mampu menunjukkan sifatsifat terpuji dan memiliki dasar-dasar kepribadian yang kuat, semua dasar-dasar ini akan berkembang secara maksimal apabila berada dalam lingkungan yang agamis pula (Hawi, 2013: 38).

Mengingat strategisnya arti keluarga dalam pembinaan akhlakini, maka orang tua harus dapat menjadi panutan dan panduan anak dalam semua aspek kehidupan, di samping memenuhi kebutuhan jasmani, orang tua juga dituntut untuk dapat memenuhi kebutuhan jiwa dari sang anak. Yakni memberikan rasa kasih sayang, 
Volume 4 Nomor 1 Edisi Juni 2019

P-ISSN : 2541-3686

rasa aman, rasa harga diri, rasa bebas dan rasa mengenal, sehingga pola interaksi antara orang tua dan anak akan terjalin secara psikis. Antara orang tua dan anak mampu saling mengelurkan isi hati, mengeluarkan pendapat, berdialog dalam memecahkan dan menyelesaikan persoalan-persoalan yang dihadapi keduanya.

Pada saat ini, perasaan anak terhadap Tuhan sudah mengarah kepada keadaan yang lebih positif bahkan hubungannya dengan Tuhan telah dipenuhi rasa aman dan percaya. Sehingga sering ditemukan pergi ke mesjid dan belajar mengaji. Tampaknya yang mendorong anak-anak tertarik dan senang pada lembaga-lembaga yang dikelolah oleh orang-orang dewasa di lingkungannaya. Pendidikan agama Isalam pada saat ini dilakukan dengan penuh kesabaran dan jangan sekali-kali memaksakan kehendak kepada anak. Cara yang tepat adalah pembinaan, latihan dan suri tauladan dari orang tua (Hawi, 2008: 183).

Oleh karena itu sejak dini telah diupayakan terbentuknya kebiasaan yang baik, sehingga anak akan lebih mudah bergaul dengan orang lain. Pada usia ini dengan perkembangan sifat sosialnya yang positif, anak siap untuk bersekolah, meskipun sebelumnya banyak yang belajar di taman kanak-kanak. Dengan maksudnya anakanak ke sekolah maka sikap sosialnya sudah mulai berkembang dengan adanya sikap ini memungkinkan anak bergaul dengan orang dewasadan teman sebayanya, untuk itu orang tua harus berusaha guru yang berakhlak baik dan beriman kepada Allah swt.

Sebagai makhluk Tuhan, sebenarnya potensi agama sudah ada pada setiap orang sejak dilahirkan. Potensi ini berupa dorongan untuk mengabdi kepada sang pencipta. Dalam terminologi Islam dorongan ini dikenal dengan bidayat al-diniyat, berupa benih-benih keberagamaan yang dianugrahkan Tuhan kepada manusia. Dengan adanya bawaan ini sebenarnya manusia adalah makhkuk beragama. Namun keberagamaan tersebut memerlukan bimbingan agar dapat tumbuh dan berkembang secara benar.

Suatu hal yang banyak menentukan dalam proses pendidikan keagamaan baik itu pada keluarga ataupun masyarakat adalah tingkat pendidikan dan pengetahuan keagamaan para orang tua dalam suatu keluarga atau masyarakat. Berangkat dari kenyataan ini tidaklah berlebihan kalau kondisi ini tidak cukup melandasi motivasi orang tua untuk mendidik anak-anaknya ke arah pendidikan keagamaan yang lebih baik, apalagi untuk menciptakan bentuk bentuk kegiatan keagamaan pada anakanak. Kendatipun ada di antara orang tua yang mengajarkan anak-anaknya pendidikan keagamaan di rumah, tetapi hal itu hanya dilakukan dengan frekuensi kecil.

Pola pendidikan Islam dalam keluaraga ataupun masyarakat, hendaklah disesuaikan dengan taraf kemampuan dan perkembangan anak. Orang tua harus mampu menajadi teladan bagi anak-anak dan mampu meyelami setiap persolan yang dihadapi anak-anak mereka sehingga dapat diselesaikan dengan cara-cara yang positif. Dengan demikian, anak mersa diperhatikan. 


\section{Pendidikan Etika Islam dalam Keluarga}

\section{Ahmad Arifai}

Dari itulah orang tua ataupun pendidik harus memperhatikan dan mengetaui pengetahuan yang luas mengenai perkembangan kiranya dapat diperoleh dengan memperhatikan pendapat-pendapat atau teori-teori dari para ahli psikologi perkembangan, teori-teori itu sedikit banyaknya dapat dijadikan sebagai landasan atau dasar-dasar untuk memajukan dan mendorong bagi perbaikan dan penyempurnaan dalam bidang pendidikan (Mustaqim, Wahib, 2010: 33).

Pendidikan agama secara umum adalah upaya untuk menjadikan manusia mampu untuk mewujudkan tujuan penciptaannya. Manusia diciptakan agar mereka mengetahui hakikat Tuhannya, mengesakan, memurnikan ibadah kepada Tuhannya dengan menghambakan diri dengan menjalankan seluruh perintah-Nya dan menjauhi semua larangan-Nya (Susanto, 2013: 277).Dan yang perlu diperhatikan setiap pendidik ataupun peserta didik adalah butir-butir etika Islam

\section{Simpulan}

Adapun kesimpulan yang bias kita ambil dari define etika Islam yang yangdapat diidentifikasikan, antara lain adalah:

1. Tuhan merupakan sumber hukum dan sumber moral kedua hal tersebut disampaikan berupa wahyu melalui para nabi dan para Rasul, dikodifikasikan ke dalam kitab-kiab suci Allah.

2. Sesuatu perbuatan adalah baik apabila sesuai dengan perintah Allah, serta didasari atas niat baik.

3. Kebaikan adalah keindahan, sedangkan tanda-tanda dosa adalah perasaan tidak enak, serta merasa tidak senang apabila perbuatannya diketahui oleh orang banyak.

4. Perikemanusiaan hendaknya berlaku bagi siapa saja, dimana saja dan kapan saja, bahkan dalam perang.

5. Anak wajib berbakti kepada orang tuanya.

Dengan memperhatikan butir-butir etika tersebut, maka peserta didik harus mampu memahami makna yang terkandung dari poin-poin yang tersurat tersebut di atas tadi sehingga mereka akan mengetahui makna dan tujuan hidup yaitu percaya bahwa Allah menciptakan manusia dengan tujuan yang mulia, dan pada dasarnya tujuan hidup manusia adalah memperoleh kebahagiaan dunia dan akhirat, sementara kewajiban atau tugas hidup manusia menurut al-Qur'an adalah mengabdi atau beriadah kepada Allah. 
RAUDHAH Proud To Be Professionals qurnal Tarbiyak7damiyak Volume 4 Nomor 1 Edisi Juni 2019

P-ISSN : 2541-3686

\section{DAFTAR PUSTAKA}

Alpiyanto. 2012, Rahasia Mudah Mendidik Dengan Hati, Bekasi: PT. Tujuh Samudra Alfath,

Anwar Abu. 2002, Ulumul Qur'an Sebuah Pengantar, Pekanbaru: Amzah

Aravik, Havis, 2018. Pengantar Studi Islam, Palembang: Rafah Press.

Azwar, Julizun Alfi. 2009, Metodologi Studi Islam: Bandung, Iris Press

Hawi, Akmal. 2008, Ilimu Jiwa Agama, Palembang: IAIN Raden Fatah Press

Hawi, Akmal. 2013. Kompetensi GuruPendidikanAgamaIslam, Jakarta:PT RajaGranpindo Persada

Isjoni. 2009, Guru Sebagai Motivator Perubahan, Yogyakarta: Pustaka Pelajar

Kementrian Agama RI 2007, Hjjaz Terjemah Tafsir Perkata. Bogor: Syaamil Qur'an

Putra Sah Thoyib, Wahyudin, 2005, Aqidah Akhlak, Semarang: PT Karya Toha Putra

Rama, Tri.Kamus Bahasa Indonesia, Surabaya: Karya Agung

Rusli. Amin. 2005,Menjadi Pribadi Simpatik, Jakarta: PT AL-MAWARDI PRIMA

Sadli, Saparinah. 1977. Persepsi Sosisal Mengenai Prilaku menyimpang, Jakarta: Bulan Bintang

Sardiman, 2014. Interaksi DanMotivasi Belajar Mengajar, Jakarta, RajaGrafindo Persada 
Pendidikan Etika Islam dalam Keluarga

Ahmad Arifai 